\title{
Obituaries
}

\section{MAUNG MAUNG GYI (1920-88)}

The world of scholarship lost a distinguished and valued member when Dr. Maung Maung Gyi died at his home in Lewiston, Maine, on July 2, 1988.

Maung Maung Gyi was born in Henzada, Burma, on September 20, 1920. He grew to maturity at a time when his country was in the midst of the nationalist struggle; his education at Judson College in Rangoon was interrupted by the Japanese invasion and World War II. In 1946 he graduated with honors in history and five years later earned his master's degree from the University of Rangoon. As a state scholar, he was sent to the United States for further training at Yale University, where he earned a master's degree in political science and, in 1958, a doctorate. Returning to Burma, he joined the faculty at University College in Mandalay, where he taught both history and political science. He was promoted to professor and served for a period as dean.

As a serious scholar who was devoted to teaching and research, he found he could not pursue his calling in Burma after the military seized power in 1962, established a political dictatorship, and sought to inculcate its views and ideology on the people and their traditional way of life. With the aid of American friends and Senator Edmund Muskie of Maine, he was able to come to the United States in 1967 and join the faculty of Bates College, where he remained as a member of the Political Science Department until retiring in June 1988.

Maung Maung Gyi will be remembered in many ways: as the author of Burmese Political Values: The Socio-political Roots of Autboritarianism (New York: Praeger Publishers, 1983) and several important articles; as a valued member of his faculty and a trustee of the Burma Studies Foundation; and as a loving husband and father. Most of all, he will be remembered as one who loved freedom and liberty so much he was willing to leave his country and live abroad in order to be true to his ideals.

$\mathrm{He}$ is survived by his wife, Hla Mya Oo, and daughter, Dr. Khin Khin Gyi. He will be missed by all who had the pleasure of knowing him, as colleague, teacher, writer, friend, husband, and father.

JOSEF SilverSTEIN

Rutgers University 